\title{
Editorial \\ How Ancestor Research Affects Self-Understanding and Well-Being: Introduction to the Special Issue
}

\author{
Susan M. Moore (D)
}

check for

updates

Citation: Moore, Susan M.. 2022. How Ancestor Research Affects Self-Understanding and Well-Being: Introduction to the Special Issue. Genealogy 6: 20. https://doi.org/ 10.3390/genealogy6010020

Received: 20 February 2022 Accepted: 23 February 2022 Published: 1 March 2022

Publisher's Note: MDPI stays neutral with regard to jurisdictional claims in published maps and institutional affiliations.

Copyright: (C) 2022 by the author. Licensee MDPI, Basel, Switzerland. This article is an open access article distributed under the terms and conditions of the Creative Commons Attribution (CC BY) license (https:// creativecommons.org/licenses/by/ $4.0 /)$.
Faculty of Health, Arts and Design, Swinburne University of Technology, Hawthorn, VIC 3122, Australia; smoore@swin.edu.au

\section{Overview}

The idea for this Special Issue of Genealogy came from my fascination not just with my own family history research, but through my involvement with groups of other passionate fellow family history researchers. As a retired psychological researcher, I was amazed at the intensity of emotions experienced by myself and others as we broke down research 'brick walls' and discovered more about our ancestors' lives. I was often moved to tears or laughter reading the stories that fellow family historians wrote on their blogs or Facebook pages, as well as being astounded at just how much enjoyable time could be spent indulging our hobby. In 2018, with Professor Emerita Doreen Rosenthal, my colleague and co-editor of this Special Issue, we conducted a survey of almost 1000 Australian hobbyist genealogists in part to answer the question, 'What motivates family historians?' We used the data collected, reviewed published literature, and took on board a fellow writer, Dr Rebecca Robinson, to produce the book, The Psychology of Family History: Exploring our Genealogy, published in 2021 by Taylor and Francis. Since we submitted our book for publication, not only has interest in family history increased greatly, so has curiosity about family historians! Research into the motives, outcomes and implications of discovering more about one's ancestors is expanding at a great rate. It seemed timely to capture some of this material in a Special Issue of Genealogy in which we 'Focus on Family Historians'.

Inviting scholars to contribute to the Special Issue, we sought articles that addressed several key topics, including explorations of the psychological and practical reasons people give for researching their family histories, the outcomes-both positive and negative-that ensue from the knowledge gained, and the notion that understanding one's ancestral background might promote personal growth and therapeutic change. A goal for the Special Issue was to foster a multi-disciplinary approach, so we sought research from sociology, psychology, history, family studies and other cognate disciplines, as well as encouraging a range of scholarly methodologies, including qualitative and quantitative empirical research, case material, literature reviews and discursive papers.

The ten articles (and one book review: (Jarvis 2021) presented here come from disciplines as varied as psychology/counselling, sociology, urban geography, theology, social work, communication studies, education and archaeology. Three general approaches are evident.

1. Scholarly interpretations of case-based material;

2. Empirical research;

3. Interpretive literature reviews.

\section{Articles Based on Family History Case Material}

Three authors (Bifulco 2021; Jarvis 2022; Parker-Drabble 2022) employed psychological theories to explain how events from their ancestral pasts such as forced migration, poverty and war can influence the personal and family narratives of current-day descendants. These narratives are the stories we tell ourselves-sometimes through feelings rather than words-about who we are and what constitutes our place in the world. They form part of 
our identity or sense of self. As each of these authors acknowledges, Attachment Theory (e.g., Ainsworth and Bell 1970; Bowlby 1969, 1982) provides a model for explaining how trauma can move through the generations. Parenting is the key. A close, warm and loving relationship between infants and their caregivers, characterised by consistency of care, engenders a child's 'secure' attachment. This involves the child developing an understanding (based on their care) that the world is a trustworthy place and that their needs will be met. This kind of attachment is postulated as the basis for assured, confident adulthood and the ability to relate to others with warmth and integrity. However, some parenting styles promote insecure attachment, for example, caregivers who are highly anxious and self-doubting, or those who are neglectful, inconsistent or lacking in warmth. Historic trauma can engender insecure parenting. Mothers in concentration camps or families suffering the duress of extreme poverty may not be able to adequately attend to their babies. These children, if they survive, may be as damaged by the poverty of their early relationships as they were by the deprivation of their physical needs. In turn, they may experience problems in relating to their own offspring. In this way, as both Parker-Drabble and Bifulco demonstrate through case studies of their own families, insecure attachment can move through the generations with outcomes such as unresolved trauma, depression or addiction.

All three writers discuss the potential healing aspects of ancestral storytelling. Jarvis, using partially fictionalised family history scenarios, argues that when historical trauma becomes part of a family's narrative, descendants may be drawn to what Freud (1961) called 'traumatic re-enactment' through fantasy. This is a process that may be therapeutic or self-defeating. We may come to see ourselves as part of a long line of either victims or heroic survivors. Jarvis coins the lovely term 'historic selfie' to describe that aspect of a personal identity crafted through the 'psychic work' of incorporating ancestral stories into our sense of who we are.

Bifulco's paper, presenting her own ancestral story of wartime tragedy and trauma, notes the importance to the mental health of survivors (and their descendants) being able to talk about their experiences, give up their secrets and give vent to emotions like grief, sorrow, fear and guilt within a safe environment. Barriers to sharing the traumas of wartime include defensive forgetting, guilt and shame, but can also involve 'public forgetting' of unacknowledged national atrocities or failures. She writes: "When trauma is unresolved it can lead to many impacts including re-experiencing of the event and hypervigilance (e.g., through nightmares and flashbacks) but also avoidance of thinking about it (even amnesia for some events) as in PTSD. This can affect other family members such as children when it is witnessed in the domestic arena".

Parker-Drabble also stresses the therapeutic value gained from hearing (or discovering) ancestral stories. These can facilitate a deeper understanding of the forces that shaped the actions and personalities of our parents, grandparents and other key elders, thus paving the way for personal growth, for example through forgiveness, increased resilience or the motivation to change maladaptive coping styles.

The use of ancestral family history in mental health interventions, while acknowledged by some (e.g., Bhar and Silver 2016; Champagne 1990; Moore et al. 2021) is not yet widely practiced. Nevertheless, as Jarvis concludes, 'the concept of historical trauma is now well poised to move into mainstream psychology'.

\section{Articles Based on Empirical Research}

Three articles in the Special Issue report empirical studies of hobbyist family historians; one is survey-based and two focus on findings derived from in-depth interviews. The study by Shaw and Donnelly (2021) presents insights into historical thinking and research practices of four Australian family historians. Using the theoretical frameworks of Jorn Rüsen's Disciplinary Matrix (Rüsen 1993) and his Typology of Historical Consciousness (Rüsen 1996), these authors conclude that engaging in genealogical research shapes and refines researchers' historical understandings and consciousness. The study supports other 
findings that amateur family historians, even those with little or no historical training, are teaching themselves about the research methods of history and the nature of reliable evidence (e.g., Hershkovitz and Hardof-Jaffe 2017). In doing so, they are making important contributions to the history discipline and, as Shaw and Donnelly put it, "shifting the historical landscape through the dissemination of their research for public consumption beyond traditional family history audiences". In addition, through their new learnings and discoveries, these hobbyist genealogists experience personal growth through greater understanding of their place within a family context that extends backwards through history and is partly shaped by it.

An empirical study by the guest editors of this Special Issue (Moore and Rosenthal 2021) used quantitative and qualitative data from a large-scale survey of Australian amateur genealogical researchers to examine the motives that drive family historians to spend so much time, effort and passion on their hobby. Additionally, the data were used to develop a pilot form of a scale to measure these motives. Factor analysis of quantitative data uncovered three underlying motives that drive family historians. The search for self-understanding (who do you think you are?) was, not surprisingly, a key motive, but so was the desire to give something of value to others (generativity) and the enjoyment of learning new things and dealing with intellectual challenges. Analysis of participants' qualitative responses suggested at least four other significant although less common drivers of genealogical research, these being motives related to spiritual or meaning-of-life quests, comfort motives, making social connections and enhancing travel experiences.

In New Zealand, Theunisson (2022) interviewed 16 individuals to explore reactions to their DNA genealogical test results. She hypothesised, and found support for, the idea that DNA matches and ethnic links influenced one's sense of both social and group identity. Interestingly, this was more strongly the case among those whose DNA data contradicted their pre-test beliefs about who they were. Some experienced an 'identity crisis' while others coped by adapting their sense of self, for example by the adoption of 'multiple identities' or through re-evaluating family relationships. The literature review by Clapton (2021) discussed in the next section takes some of these ideas further for the special case of those who find out late in life that they are adopted, in many cases prompting a huge and often emotional reassessment of personal identity.

With the upsurge of interest in genealogical DNA testing and family history research, there is still tremendous opportunity for further empirical studies to assess the role that knowledge of ancestors and of previously unknown living relatives plays in mental health and wellbeing. There is much to be learned about the various ways that knowledge is shaped into personal and family narratives of success and failure, strength and weakness, resilience and vulnerability.

\section{Articles Comprising Interpretive Literature Reviews}

Four very different aspects of heritage are discussed and evaluated in papers by Aplin (2021); Robinson (2021); Clapton (2021) and Büster (2022). Aplin emphasises the importance of context in researching and understanding one's family history. Researching the economic, political, social and domestic behaviours, traditions and moral codes of our ancestors adds fruit and flowers to the family tree, as Aplin puts it. Such research can also engender strong feelings. It is not unusual for genealogical researchers to develop emotional attachments to places where their ancestors lived, suffered or thrived. The affective pull of heritage is also reflected in our attachments to certain family items, traditions and routines. In the wider context, we come to value objects, activities, or geographic features of the nation or nations that we identify as the source of our cultural heritage. Currently citizens from many countries are challenging which features of a nation should 'count' and be valued as heritage. This is demonstrated through, for example, rejecting once-admired monuments, or re-interpreting the importance of past 'heroes'. Whether these actions are appropriate or not, they certainly underline the sensitive role of heritage in our individual, family, local and national stories. 
In her article about the parallels between religious practices and the valuing of personal heritage, Robinson discusses the ways in which ancestor research has become 'sacred practice in a secular age'. Three aspects of ancestor research are highlighted: the inheritance of 'sacred' stories and objects with familial significance; acts of pilgrimage to ancestrally significant places; and participation in 'ritual' gatherings, either with extended family or with others who share similar genealogical interests. Robinson argues that, like religion, genealogical practice can involve a spiritual element, and also like religion, can foster and strengthen feelings of identity, purpose, and belonging. As family historians, we honour our ancestors by telling their stories, continuing their traditions, making 'pilgrimages' to walk in their footsteps, and keeping alive family connections. These behaviours can contribute to our feelings of spiritual comfort and life meaning.

Büster's research and review is also about acknowledgement and honouring of ancestors, in this case from a 'deep time perspective', that is, by considering archaeological evidence from pre-literate societies and pre-historic times. Findings from the Iron Age, including domestic family items hidden in the walls of houses, are interpreted as ways of maintaining continuing bonds with the dead. Puzzling findings such as skeletal remains in which bones from several people are mixed in purposeful ways, or 'mummy bundles' in which the mummy is made up of the bones of more than one individual, raise questions as to the evolution of modern ideas of family and personhood. Büster's research review reminds us that forms of genealogy and ancestor veneration have a very, very long history. In her words, "The deep-time and global perspective presented here demonstrates that our relationships with ancestors are complex and multi-faceted, that concepts of ancestor and kin are culturally and contextually specific, and, whether positive or negative, comforting or problematic, ancestors are an ever-present and ubiquitous part of life".

Finally, Clapton's article brings us back to a modern-day issue that has loomed large since the advent of readily available DNA testing and is likely to become an even hotter topic since the more widespread use of various forms of donor conception. Clapton's paper reviews what we know about the experiences of adopted people who discover in later life that they are adopted. Without a doubt, this 'emotional bombshell' can give rise to identity conflict, a sense of betrayal and breach of trust, as individuals in this situation reflect, 'If they can keep this a secret from me, what else are they not telling me?' Some experience feelings of loss and grief as kinship knowledge, and therefore cultural and self-knowledge, are disrupted. Strong emotions like distress, anger and confusion emanate from stories told by those who discover they are not who they thought they were. While many develop ways of coping and re-shape their identities to incorporate biological and non-biological families, their stories underline the importance of giving adopted and donor-conceived children the opportunity to know about their origins from an early age.

\section{Conclusions}

The stories we tell about our personal, family, clan, tribal and national past all contribute to our sense of who we are-an internal narrative that shapes our self-esteem and confidence in the world. For most of us, that internal narrative is a mix of positive and negative elements - there are things we take pride in and things that shame us. To survive and prosper, psychology tells us it is better to focus on the positive, but sometimes to do that we have to first face our demons. The widespread leisure pastime of family history has, for many of us, expanded our personal narrative into the past, and given us not only an interest but a cause for excitement and joy as we discover new, colourful, even heroic characters in our family story. However, we can also feel shame or sadness as we unearth forebears who behaved badly, whose lives were 'nasty, brutish and short', or those who experienced unjust treatment, tragedy and despair. The way we balance the pride and shame, joy and sorrow, tragedy and triumph of our ancestral past will in turn shape the personal narrative of just who 'we think we are' and the family narratives that we choose to pass on to our descendants. 
National histories reveal similar features. Politicians, historians, the media and other influencers present their nation's history as stories that define a 'national narrative'. As with family histories, there will be tensions between the positive and negative accounts of past events. How can these tensions be reconciled to enable constructive growth in ways that are healthy for the nation as a whole, yet acknowledge past wrongs? And, just as family historians' understanding of their ancestors' lives is enhanced by considering the broader context in which they lived, so might the understanding of world history be enhanced by the cumulative findings of family historians as they explore the lives of ordinary folk. The 'big picture' and 'little picture' approaches have the potential to be mutually beneficial to knowledge and reconciliation; a potential that has not yet been fully explored.

As well as the interrelationships between academic history research and that of family historian 'amateurs', there are many avenues (or rabbit holes!) not yet explored in researching the social and personal influences and outcomes of genealogical research. In the papers that comprise this Special Issue, many topics have been raised but not yet fully examined, for example issues relating to history education, heritage preservation, psychotherapeutic interventions, 'genealogical travel', ethical/legal issues facing family historians, and even what we mean by personal identity, family, and ancestry. As more historical documents, archaeological findings and DNA discoveries become accessible to scholars and amateur researchers alike, it is probable that interest in family history research will remain high. What we hope to have begun with this Special Issue is recognition of the opportunities to 'research the researchers', to find out more about what makes family historians tick and the potential of family history research to contribute not only to knowledge but to wellbeing.

Funding: This research received no external funding.

Acknowledgments: First: I would like to thank my co-editor Emerita Doreen Rosenthal whose support and wise counsel contributed significantly to the successful production and quality of this Special Issue. Second, thank-you to the anonymous reviewers whose time, knowledge and mental effort helped to shape and polish these published papers. Thank-you also to the Assistant Editors for their advice and assistance in ensuring that the many processes needed prior to publication were efficiently conducted in a timely manner. Special thanks are due to the Managing Editor of the Special Issue, who steered me though the processes with patience, efficiency and tact. Finally, a sincere thank-you to the authors who worked so hard to present their unique contributions to understanding the psychological impacts of family history research.

Conflicts of Interest: The author declares no conflict of interest.

\section{References}

Ainsworth, Mary D., and Silvia M. Bell. 1970. Attachment, exploration, and separation: Illustrated by the behavior of one-year-olds in a strange situation. Child Development 41: 49-67. [CrossRef] [PubMed]

Aplin, Graeme. 2021. Context: The role of place and heritage in genealogy. Genealogy 5: 58. [CrossRef]

Bhar, Sunil, and Mark Silver. 2016. Life as a Story: The Use of Digital Life Story Work in Residential Aged Care Settings in Australia. InPsych 38: 32-33. Available online: https://www.psychology.org.au/inpsych/2016/april/bhar (accessed on 15 February 2022).

Bifulco, Antonia. 2021. Family history and searching for hidden trauma-A personal commentary. Genealogy 5: 46. [CrossRef]

Bowlby, John. 1969. Attachment and Loss. OKS Print. New York: Basic Books.

Bowlby, John. 1982. Attachment and loss: Retrospect and prospect. American Journal of Orthopsychiatry 52: 664-78. [CrossRef] [PubMed] Büster, Lindsey. 2022. From human remains to powerful objects: Ancestor research from a deep-time perspective. Genealogy 6. in press. Champagne, Delight E. 1990. The genealogical search as a counseling technique. Journal of Counseling E Development 69: 85-87.

Clapton, Gary. 2021. Family histories, family stories and family secrets: Late discoveries of being adopted. Genealogy 5: 105. [CrossRef] Freud, Sigmund. 1961. Beyond the Pleasure Principle. Translated by James Strachey. New York: W. W. Norton and Company. Hershkovitz, Arnon, and Sharon Hardof-Jaffe. 2017. Genealogy as a lifelong learning endeavor. Leisure/Loisir 41: 535-60. [CrossRef] Jarvis, Pam. 2021. Book Review: The Psychology of Family History. Genealogy 5: 39. [CrossRef]

Jarvis, Pam. 2022. Ancestral selfies and historical traumas: Who do you feel you are? Genealogy 6: 1. [CrossRef]

Moore, Susan M., and Doreen A. Rosenthal. 2021. What motivates family historians? A pilot scale to measure psy-chosocial drivers of research into personal ancestry. Genealogy 5: 83. [CrossRef]

Moore, Susan, Doreen Rosenthal, and Rebecca Robinson. 2021. The Psychology of Family History: Exploring Our Genealogy. Abingdon: Taylor \& Francis. 
Parker-Drabble, Helen. 2022. How key psychological theories can enrich our understanding of our ancestors and help improve mental health for present and future generations: A family historian's perspective. Genealogy 6: 4. [CrossRef]

Robinson, Rebecca. 2021. Pilgrimage and purpose: Ancestor research as sacred practice in a secular age. Genealogy 5: 90. [CrossRef]

Rüsen, Jorn. 1993. The development of narrative competence in historical learning: An ontogenetic hypothesis concerning moral consciousness. In Studies in Metahistory. Edited by Jorn Rüsen. Pretoria: Human Sciences Council.

Rüsen, Jorn. 1996. Some theoretical approaches to intercultural comparative historiography. History and Theory 35: 5-22. [CrossRef]

Shaw, Emma L., and Debra J. Donnelly. 2021. (Re)discovering the familial past and its impact on historical con-sciousness. Genealogy 5: 102. [CrossRef]

Theunisson, Catherine Agnes. 2022. The effects of DNA test results on biological and family identities. Genealogy 6: 17. [CrossRef] 